\title{
Clinical Significance of Bronchodilator Responsiveness Evaluated by Forced Vital Capacity in COPD: SPIROMICS Cohort Analysis [Corrigendum]
}

Barjaktarevic IZ, Buhr RG, Wang X, et al. Int J Chron Obstruct Pulmon Dis. 2019;14:2927-2938.

The authors have advised that there is an error in the Funding section on page 2935. The correct funding statement is as follows:

\section{Funding}

This study was supported by R01HL125432-01A1 (MBD), T32HL007106-41 (RMB), and TL1TR001883-01 (RGB). SPIROMICS was supported by contracts from the NIH/ NHLBI (HHSN268200900013C, HHSN2682009 00014C, HHSN268200900015C, HHSN268200900016C, HHSN2 68200900017C, HHSN268200900018C, HHSN268200 900019C, and HHSN268200900020C) and supplemented by contributions made through the Foundation for the NIH and the COPD Foundation from AstraZeneca/MedImmune, Bayer, Bellerophon Therapeutics, Boehringer-Ingelheim Pharmaceuticals, Inc., Chiesi Farmaceutici S.p.A., Forest Research Institute, Inc., GlaxoSmithKline, Grifols Therape -utics, Inc., Ikaria, Inc., Nycomed GmbH, Takeda Pharmaceutical Company, Novartis Pharmaceuticals Corporation, ProterixBio; Regeneron Pharmaceuticals, Inc., Sanofi, and Sunovion. The PRM analyses were supported by NHLBI HL122438 and HL138188. Mehrdad Arjomandi was supported by a grant from the Flight Attendant Medical Research Institute.

The authors apologize for this error.

\section{Publish your work in this journal}

The International Journal of COPD is an international, peer-reviewed journal of therapeutics and pharmacology focusing on concise rapid reporting of clinical studies and reviews in COPD. Special focus is given to the pathophysiological processes underlying the disease, intervention programs, patient focused education, and self management protocols. This journal is indexed on PubMed Central, MedLine and CAS. The manuscript management system is completely online and includes a very quick and fair peer-review system, which is all easy to use. Visit http://www.dovepress.com/testimonials.php to read real quotes from published authors. 